\title{
MANAJEMEN STRATEGI DAN MANAJEMEN MUTU TERPADU
}

\author{
"Sebagai Kajian Manajemen Kurikulum Pendidikan Islam"
}

Oleh: Agus Lestari

\begin{abstract}
Abstrak:
Tulisan ini mendiskripsikan tentang pentingnya Manajemen Strategis dan Manajemen Mutu Terpadu terhadap pendidikan baik pendidikan secara umum maupun pendidikan Islam pada khususnya. Lebih Khusus lagi tulisan ini berkaitan dengan betapa pentingnya Manajemen Strategi Dan Manajemen Mutu Terpadu sebagai kajian Manajemen Kurikulum Pendidikan Islam. Dikatakan penting, karena Manajemen Strategis dan Manajemen Mutu terpadu sangat memberikan manfaat dalam perencanaan kurikulum. Sekolah merupakan institusi pendidikan yang hampir sama dengan korporasi- korporasi lainnya yang memerlukan perencanaan strategis untuk menentukan arah jalannya organisasi sekolah supaya lebih jelas arah kebijakan yang akan diambil. Perencanaan strategis dapat memberikan banyak manfaat dilingkungan sekolah atau madrasah bila dibandingkan dengan kelemahkelemahannya
\end{abstract}

Kata Kunci: Manajemen Strategi, Manajemen Mutu, Kurikulum Pendidikan Islam 


\section{PENDAHULUAN}

\section{A. LATAR BELAKANG MASALAH}

Di dalam UUD 1945 dinyatakan bahwa tujuan kita membentuk Negara Kesatuan Republik Indonesia diantaranya adalah untuk mencerdasakan kehidupan bangsa. Bangsa yang cerdas adalah bangsa yang dapat bangkit di dalam menghadapi berbagai kesulitan. Kenyataanya dewasa ini bangsa Indonesia sedang dilanda dan masih berada di tengah-tengah krisis yang menyeluruh, termasuk di dalam bidang pendidikan. Sesungguhnya semenjak jaman perjuangan kemerdekaan dahulu, para pejuang serta perintis kemerdekaan telah menyadari bahwa pendidikan merupakan faktor yang sangat vital dalam usaha untuk mencerdaskan kehidupan bangsa.

Membangun pendidikan yang baik harus diciptakan lingkungan pembelajaran yang baik. Membangun lembaga- lembaga pendidikan yang baik, mampu mencetak sumber daya manusia yang cerdas, pintar, mandiri, religious dan berkarakter siap bersaing dengan Negara Negara lain. Hal ini semua harus disiapkan secara matang dengan manajemen strategis dan manajemen mutu terpadu, untuk menciptakan program-program pendidikan yang berkualitas antara lain: Program kurikulum, Program ketenagaan, Program pengadaan dan pemeliharaan fasilitas dan alat-alat pendidikan, Program pembiayaan, Program hubungan dengan masyarakat.

Berangkat dari hal itu penulis tertarik membuat karya tulis dengan judul Manajemen Strategi Dan Manajemen Mutu Terpadu "Sebagai Kajian Manajemen Kurikulum Pendidikan Islam”. 


\section{PEMBAHASAN}

\section{A. MANAJEMEN STRATEGI}

Manajemen adalah merupakan suatu proses untuk mewujudkan tujuan yang di ingnkan. ${ }^{1}$ Sebagai ilmu pengetahuan, manajemen bersifat universal dan mempergunakan kerangka ilmu pengetahuan yang sistematis mencakup kaidahkaidah, prinsip-prinsip dan konsep-konsep yang cenderung benar dalam semua situasi manajerial. Ilmu pengetahuan manajemen dapat diterapkan dalam semua organisasi manusia seperti: perusahaan, pemerintah, pendidikan, sosial, keagamaan, dan lain sebagainya. ${ }^{2}$

Lalu bagaimana konsep tentang manajemen tersebut dalam pandangan Islam?.Ramayulis ${ }^{3}$ menyatakan bahwa pengertian yang sama dengan hakikat manajemen adalah al-tadbir (pengaturan). Kata ini merupakan derivasi darikata dabbara (mengatur) yang banyak terdapat dalam AlQur'an. Sebagaimana firman Allah SWT dalam surah al-Sajadah ayat 5:

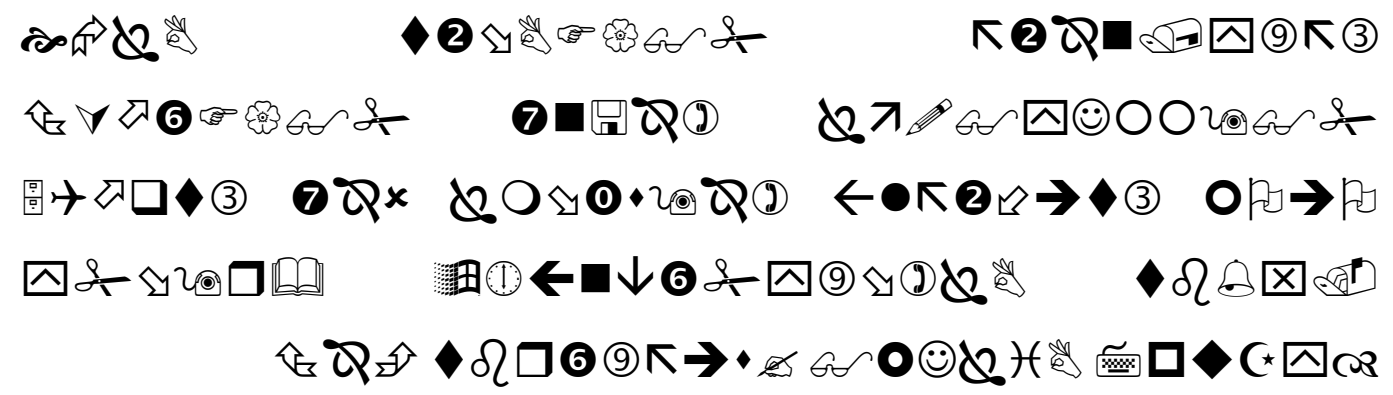

Artinya: Dia mengatur urusan dari langit ke bumi, kemudian (urusan) itu naik kepadanya dalam satu hari yang kadarnya adalah seribu tahun menurut perhitunganmu ${ }^{4}$

Berdasarkan isi kandungan ayat diatas menegaskan bahwa Allah adalah pengaturalam (Dzat Yang Maha Mengatur: manager). Keteraturan alam raya ini merupakan bukti kebesaran Tuhan dalam mengelola alam ini. Namun, karena

\footnotetext{
${ }^{1}$ Alex Gunur, Manjemen Kerangka-Kerangka Pokok (Jakarta: Bhratara Karya Aksara, 1982), 15.

${ }^{2}$ T. Hani Handoko, Manajemen (Yogyakarta: BPFE, 1999), 6.

${ }^{3}$ Ramayulis,IlmuPendidikanIslam (Jakarta: KalamMulia,2008), 362.

${ }^{4}$ Maksud urusan itu naik kepadanya ialah beritanya yang dibawa oleh malaikat. ayat ini suatu tamsil bagi kebesaran Allah dan keagunganNya.
} 
manusia yang diciptakan AllahSWT telah dijadikan sebagai khalifah dibumi, maka dia harus mengatur dan mengelola bumi dengan sebaik-baiknya sebagaimana Allah mengatur alam raya ini.

Pada hakikatnya, manajemen berkenaan dengan cara-cara pengelolaan suatu lembaga agar lembaga tersebut efisien dan efektif. Suatu lembaga akan efisien apabila investasi yang ditanamkan didalam lembaga tersebut sesuai atau memberikan provit sebagaimana yang diharapkan. Selanjutnya, suatu institusi akan efektif apabila pengelolaannya menggunakan prinsip-prinsip yang tepat dan benar sehingga berbagai kegiatan didalam lembaga tersebut dapat mencapai tujuan sebagaimana yang telah direncanakan. ${ }^{5}$

Strategi menurut Gaffar adalah rencana yang mengandung cara komrehensif dan integrative yang dapat dijadikan pegangan untuk bekerja, berjuang, dan berbuat guna memenangkan kompetisi. Secara historis konsep strategi berasal dari militer, kemudian dikembangkan di dunia bisnis dan dunia kehidupan lainnya seperti politik dan pendidikan.

Unsur-unsur umum dalam strategi adalah prinsip prinsip dalam bargaining, threats, mutuals distrusts, balanced antara kerja sama dan konflik. Definisi diatas cukup berbeda dengan apa yang disampaikan Norman dan Ramires, strategi adalah menciptakan suatu yang bernilai. Definisi ini sejalan dengan Porter yang menyatakan bahwa strategi adalah posisi yang kompetitif dan deferensial menurut pelanggan, dan menambah nilai melalui sebuah perbedaan kegiatan variatif dari pesaing.

Strategi merupakan instrument manajemen yang urgen dan tidak dapat dihindari termasuk didalam manajemen sekolah. Strategi sekolah memastikan dan pendekatan yang digunakan untuk mencapai tujuan strategiknya. Langkah ini dalam proses manajemen strategic sekolah/madrasah mencakup identifikasi masalah pilihanpilihan strategis yang mungkin dapat dilakukan untuk mencapai tujuan sekolah,

${ }^{5}$ H.A.R.Tilaar, Membenahi PendidikanNasional (Jakarta: PT.Rineka Cipta, 2002), 10. 
evaluasi alternative-alternatif strategi dengan menggunakan yang pasti dan pilihan sebuah alternative atau kelompok yang mungkin menjadi strategi sekolah.

Manajemen strategi adalah suatu proses yang berkenaan dengan penentuan arah masa depan suatu organisasi dan pelaksanaan keputusan dalam rangka mencapai sasaran jangka pendek dan jangka panjang. Menurut Lubis manajemen strategi merupakan proses iterative yang kontinyu untuk menyelaraskan organisasi secara keseluruhan terhadap lingkungannya. ${ }^{6}$

Dari beberapa uraian diatas, dapat disimpulkan bahwa manajemen strategi merupakan usaha yang terencana secara sistemik untuk membawa korporasi selalu menyesuaikan dengan perubahan tuntutan lingkungan internal dan eksternal dalam rangka memastikan diri korporasi dapat mencapai tujuan dan sasaran korporasi secara optimal. Maka manajemen strategis memiliki beberapa unsure keputusan korporasi, perencanaan yang matang, dan pemilihan strategis. ${ }^{7}$

\section{B. MANAJEMEN MUTU TERPADU}

Paradigma Total Quality Management ( TQM ) merupakan suatu pendekatan dalam menjalankan usaha yang mencoba untuk memaksimumkan daya saing organisasi melalui perbaikan terus menerus atas produk, jasa, manusia, proses, dan lingkungannya.

Tujuan utama TQM adalah untuk mereorientasi sistem manajemen, perilaku staf, fokus organisasi dan proses-proses pengadaan pelayanan sehingga lembaga penyedia pelayanan bisa berproduksi lebih baik, pelayanan yang lebih efektif yang memenuhi kebutuhan, keinginan dan keperluan pelanggan..

Manfaat utama penerapan TQM pada sektor publik adalah perbaikan pelayanan, pengurangan biaya dan kepuasan pelanggan. Perbaikan progresif dalam sistem manajemen dan kualitas pelayanan menghasilkan peningkatan kepuasan pelanggan.

${ }^{6}$ Ahmadi, Manajemen Kurikulum: Pendidikan Kecakapan Hidup (Yogyakarta: Pustaka Ifada, 2013), 29-30.

${ }^{7}$ D. Mulyasana, Pendidikan Bermutu dan Berdaya Saing (Bandung: PT. Remaja Rosda Karya, 2011), 190. 
Sebagai tambahan, manfaat lain yang bisa dilihat adalah peningkatan keahlian, semangat dan rasa percaya diri di kalangan staf pelayanan publik, perbaikan hubungan antara pemerintah dan masyarakatnya, peningkatan akuntabilitas dan transparansi pemerintah serta peningkatan produktifitas dan efisiensi pelayanan publik .

TQM hanya dapat dicapai dengan memperhatikan karakteristik sebagai berikut:

1. Fokus pada pelanggan, baik pelanggan internal maupun eksternal.

2. Memiliki obsesi yang tinggi terhadap kualitas.

3. Menggunakan pendekatan ilmiah dalam pengambilan keputusan dan pemecahan masalah.

4. Memiliki komitmen jangka panjang.

5. Membutuhkan kerjasama tim (teamwork).

6. Memperbaiki proses secara berkesinambungan.

7. Menyelenggarakan pendidikan dan pelatihan.

8. Memberikan kebebasan yang terkendali.

9. Memiliki kesatuan tujuan.

10. Adanya keterlibatan dan pemberdayaan karyawan.

Prinsip-prinsip yang mempedomani TQM mencakup:

1. promosi lingkungan yang berfokus pada mutu.

2. pengenalan kepuasan pelanggan sebagai indikator kunci pelayanan bermutu.

3. perubahan sistem, perilaku dan proses dalam rangka menjalankan perbaikan selangkah demi selangkah dan terus menerus terhadap barang dan pelayanan yang disediakan oleh sebuah organisasi .

Manajemen Mutu Terpadu atau lebih dikenal dengan istilah Total Quality Management (TQM) pertama kali diperkenalkan oleh Dr. William Edwards Deming (1986) pada akhir tahun 1950-an. Ide-idenya tidak diterima oleh industriindustri AS 
tetapi pada akhirnya disahkan olehJepang dalam pemulihan mereka dari Perang Dunia II. Sebagai hasil dari implementasi TQM, konsep "made in Japan" telah berubah dari suatu masa penghinaan menjadi suatu kata-kata pujian yang besar. Pada tahun 1980-an, industriindustri AS mulai melihat nilai dari pendekatan TQM. Perusahaan-perusahaan seperti Motorola dan Federal Express yang dulunya telah gagal, sekarang menjadi perusahaan pemimpin dunia. Motorola sekarang ini melakukan suatu transaksi penjualan bisnis dengan Jepang. Di dalam tulisan ini, prinsip-prinsip TQM diuraikan dengan penekanan pada pentingnya mengidentifikasi pelanggan dan menganalisis prosesnya. "14 poin" Deming membentuk suatu kerangka implementasi TQM, yang telah diterapkan pada lingkungan akademik berdasarkan pengalaman yang diperoleh dari The Air Force Academy. Deming telah secara luas dikenal sebagai "Bapak" dari gerakan TQM. Dia juga dikenal dengan konsep "3 C" yang berfokus pada Customer (pelanggan), Culture (budaya), dan Capacity (kapasitas) untuk perbaikan berkesinambungan yang merupakan suatu bentuk lingkungan mutu terpadu di mana banyak organisasi yang sukses telah menggunakannya untuk meremajakan diri mereka sendiri. Di bawah ini ada beberapa klarifikasi mengenai "3 C", yaitu:

\section{The Customer}

Mutu terpadu mempunyai dua macam pelanggan, yaitu:

a. Pelanggan eksternal, yang "membeli” barang atau jasa yang ditawarkan.

b. Pelanggan internal, yang terlibat dalam proses menciptakan barang atau jasa, menerima output dari pekerjaan lainnya dengan setiap orang. sukses yang menambahkan beberapanilai.

\section{The Culture}

Suatu strategi perubahan yang sukses melibatkan pengelolaan mutu, juga melibatkan komitmen untuk menciptakan suatu jenis budaya organisasi yang spesifik, berdasarkan pada kepercayaan dan pengambilan keputusan bersama. 


\section{The Capacity}

Para pemimpin di dalam organisasi-organisasi yang berorientasi pada mutu melihat cara-cara yang tidak hanya berubah tetapi untuk mengelola dan menanamkan proses perubahan itu. Dalam istilah Deming, mereka mencapai "tujuan yang konstan”. TQM merupakan perpaduan dari fungsi-fungsi dan proses terkait ke dalam siklus hidup produksi pada tahap-tahap yang berbedabeda seperti desain, perencanaan, produksi, distribusi, dan pelayanan. Ukuran keberhasilan TQM merupakan kepuasan pelanggan dan cara mencapainya melalui desain sistem dan peningkatan terus-menerus. TQM juga merupakan pendekatan untuk meningkatkan efektivitas dan daya lentur sebuah organisasi secara keseluruhan dengan berpusat di sekitar mutu. TQM pada prinsipnya adalah cara mengorganisasikan dan mengerahkan seluruh organisasi, setiap bagian, aktivitas, dan individu pada setiap tingkat untuk mencapai kualitas. TQM terkait dengan masalah strategis, pemasaran, dan aspekaspek manusia dari organisasi.

\section{Prinsip-prinsip TQM di Sekolah}

Salah satu faktor yang paling berpengaruh di dalam kesuksesan atau kegagalan dari usaha implementasi TQM adalah pengesahan secara universal, terutama pada pimpinan sekolah. Jika pimpinan sekolah tidak berusaha membuat konsep TQM diterima, itu tidak mungkin bahwa usaha implementasi TQM akan menjadi sukses. Mengesahkan konsep TQM mewakili suatu perubahan mendasar di dalam cara seseorang melakukan usaha. Selain itu, dibutuhkan dukungan dari setiap orang dalam rantai komando sekolah, mulai dari guru sampai kepala sekolah. Akan tetapi, penting juga mendapatkan pengesahan dari siswa. TQM adalah suatu filosofi manajemen partisipatif dan siswa telah berpartisipasi di dalam seluruh usaha. Tanpa suatu proses pendidikan, kita tidak akan mempunyai dukungan dari siswa. Suatu komitmen waktu dibuat untuk melaksanakan TQM, tahap pertama adalah mengidentifikasi "pelanggan" atau stakeholder. Untuk melakukan ini, kita harus menjaga proses pendidikan sebagai suatu sistem, di mana semua unsur dan interaksi 
di antara unsur-unsur sekolah harus diarahkan. Perbaikan proses seharusnya dimulai dan diakhiri oleh pelanggan. Dengan mengidentifikasi siswa dan karyawan dari sekolah kita sebagai pelanggan utama kita, kita akan dapat memuaskan semua pelanggan lainnya di sekolah seperti orang tua, masyarakat, komite sekolah, pemerintah, dan lain sebagainya. Akan tetapi, siswa biasanya diperlakukan lebih sebagai produk daripada sebagai pelanggan. Ini adalah suatu kasus klasik dari tidak tepatnya mendefinisikan sistem. Semua pihak yang relevan harus termasuk di dalam sistem pendidikan. Jika semua pihak diidentifikasi, maka kepentingan relatif dari masing-masing pihak dapat ditetapkan. Jika siswa diidentifikasi sebagai salah satudari pelanggan kita, kita harus mencoba untuk memuaskan pelanggan, tetapi kita harus yakin akan mengetahui apa yang sebenarnya diinginkan pelanggan. Para pelanggan harus membuat keputusan yang terinformasi dalam menentukan apa yang mereka inginkan, memperhitungkan biaya-biaya, kinerja yang dibutuhkan, masalah hukum, dan sebagainya. Mt. Edgecumbe (1994) mengimplementasikan prinsipprinsip TQM menurut versi adaptasi "14 poin Deming" untuk kualitas di dalam organisasi. Poin-poin di bawah ini direproduksi seluruhnya dan menggunakan jenis huruf tebal untuk ide-ide kuncinya.

1. Menciptakan dan memelihara ketepatan tujuan untuk meningkatkan layanan terhadap siswa dan sekolah. Tujuannya adalah untuk menciptakan siswa berkualitas terbaik yang mampu memperbaiki semua bentuk proses dan memasuki posisi yang berarti di masyarakat.

2. Menganut filosofi baru. Manajemen sekolah harus menyadari tantangan, harus mempelajari tanggung jawab mereka, dan mengambil kepemimpinan untuk berubah.

3. Bekerja untuk menghapuskan angka dan pengaruh-pengaruh berbahaya dari penilaian terhadap siswa. Berfokus padaproses pembelajaran, bukan proses penilaian terhadap siswa.

4. Menghentikan ketergantungan pada ujian untuk mencapai mutu. Menghapus 
kebutuhan untuk inspeksi pada suatu dasar massal (ujian-ujian prestasi yang terstandarisasi) dengan menyediakan pengalaman pembelajaran yang dapat menciptakan kinerja yang berkualitas; pengalaman pembelajaran yang dapat memotivasi kreativitas serta eksperimentasi.

\section{Bekerja dengan institusi-institusi pendidikan tempat siswa berada.}

Meminimalkan total biaya pendidikan dengan cara meningkatkan hubungan dengan sumber-sumber siswa dan membantu meningkatkan mutu siswa yang menerima sistem pendidikan.

\section{Terus-menerus dan selalu memperbaiki sistem untuk meningkatkan layanan} terhadap siswa dan pendidikan dalam rangka meningkatkan mutu dan produktivitas dalam kehidupan pribadi dan masyarakat.

7. Terus-menerus melembagakan pelatihan dalam jabatan bagi siswa, guru, staf khusus dan administrator; bagi semua orang yang berhubungan dengan organisasi kemanusiaan atau masyarakat.

8. Melembagakan kepemimpinan. Tujuan dari supervisi atau kepemimpinan di sekolah seharusnya adalah untuk membantu guru dan staf sekolah dalam menggunakan teknologi dan materi untuk melakukan pekerjaan yang lebih baik serta menentukan kecepatan untuk menggerakkan kreativitasnya.

9. Mengusir ketakutan, supaya setiap guru dan staf sekolah bekerja secara efektif untuk suatu sistem sekolah. Ciptakan lingkungan sekolah yang memotivasi warga sekolah untuk berbicara dengan bebas dan mengambil risiko.

10. Mematahkan rintangan di antara bagianbagian. Orang di bagian pengajaran, pendidikan khusus, akuntansi, kantin, administrasi, pengembangan kurikulum dan penelitian harus bekerja sebagai suatu tim. Kembangkan strategi-strategi untuk meningkatkan kerjasama di antara kelompok dengan individu. Merencanakan waktu akan memfasilitasi dinamika ini.

11. Menghapus slogan, pernyataan, dan target bagi guru dan siswa yang meminta kinerja yang sempurna dan tingkat produktivitas yang baru. Suatu 
pernyataan dapat menciptakan hubungan perselisihan. Penyebab rendahnya kualitas dan produktivitas termasuk sistemnya ada di bawah kendali guru dan siswa.

12a. Menghapus standar-standar pekerjaan (quota) guru dan siswa (misalnya, nilai ujian naik 10\%; angka putus sekolah turun 15\%). Mengganti kepemimpinan, gerakan terus-menerus untuk mutu, dan pembelajaran yang menyenangkan.

12b.Menghilangkan rintangan-rintangan yang merampas siswa, guru dan manajemen (kepala sekolah, pengawas sekolah dan staf pendukung di kantor sekolah) dari hak-hak mereka untuk bangga dan menikmati kecakapan kerja. Ini berarti penghapusan dari peringkat tahunan atau peringkat jasa dan dari management by objective (MBO). Tanggung jawab dari semua pemimpin pendidikan harus berubah dari paradigm kuantitas kepada paradigma kualitas.

\section{Melembagakan suatu program pendidikan dan perbaikan diri yang kuat} bagi setiap orang. Kemampuan guru dan manajemen sekolah ditingkatkan melalui pendidikan formal untuk mencapai jenjang pendidikan yang lebih tinggi. Mereka juga didorong dan difasilitasi untuk meningkatkan kualitas dirinya.

\section{Menempatkan setiap orang dalam masyarakat untuk bekerja melakukan}

transformasi. Transformasi merupakan pekerjaan dari setiap stakeholders sekolah.

Partisipasi aktif dari stakeholders sekolah harus didorong dan dikembangkan secara terpadu untuk membudayakan mutu sekolah. Ketika TQM sukses diterapkan, maka itu menghasilkan suatu studi yang mendalam dari setiap poin di atas dan penentuan yang jelas dari bagaimana setiap tahapnya diterapkan ke dalam situasi sekolah yang ada. Implementasi TQM yang dilakukan akan tergantung pada ukuran institusi pendidikan, apakah itu institusi swasta atau pemerintah, dan kekuatan dari setiap orang yang terlibat, tetapi variabel yang paling penting adalah kedewasaan siswa dan 
keterlibatan dari karyawan sekolah. Prinsipprinsip TQM dapat diterapkan di dalam proses pendidikan pada sekolah dasar, sekolah menengah pertama, dan sekolah menengah atas. ${ }^{8}$

\section{Konsep TQM dalam Pendidikan}

Menurut W. Edward Deming, salah seorang pioner kualitas menyatakan bahwa kualitas itu memiliki banyak kriteria yang selalu berubah. Namun demikian, definisi kualitas yang diterima secara umum mencakup elemen-elemen berikut : (1) mempertemukan harapan pelanggan (customer), (2) menyangkut aspek produk, servis, orang, proses dan lingkungan, dan (3) kriteria yang selalu berkembang yang berarti bahwa sebuah produk sekarang termasuk berkualitas, tetapi di lain waktu mungkin tidak lagi berkualitas. Jadi, kualitas adalah sesuatu yang dinamis yang selalu diasosiasikan dengan produk, servis, orang, proses, dan lingkungan.

Edward Sallis memandang bahwa kualitas itu memang sesuatu yang tarik menarik antara sebagai konsep yang absolut dan relatif. Namun, ia menegaskan bahwa kualitas sekarang ini lebih digunakan sebagai konsep yang absolut. Karena itu, kualitas mempunyai kesamaan arti dengan kebaikan, keindahan, dan kebenaran; atau keserasian yang tidak ada kompromi. Standar kualitas itu meliputi dua, yaitu; kualitas yang didasarkan pada standar produk/jasa; dan kualitas yang didasarkan pada pelanggan (customer). Kualitas yang didasarkan pada produk/jasa, memiliki beberapa kualifikasi: (1) sesuai dengan spesifikasi, (2) sesuai dengan maksud dan kegunaannya, (3) tidak salah atau cacat, dan (4) benar pada saat awal dan selamanya. Sementara itu, kualitas yang didasarkan pada customer, mempunyai kualifikasi; (1) memuaskan pelanggan (costomer satisfaction), (2) melebihi harapan pelanggan, dan (3) mencerahkan pelanggan. Tiga guru kualitas, yaitu Philip Crosby, Edward Deming dan Joseph Juran menyatakan bahwa komitmen yang harus dibangun dalam setiap

8 David wijaya, Implementasi Manajemen Mutu Terpadu dalam Penyelenggaraan Pendidikan di sekolah "Jurnal Pendidikan Penabur - No.10/Tahun ke-7/Juni 2008,hlm 89 
diri terhadap kualitas adalah pemahaman bahwa : Pertama, kualitas merupakan kunci ke arah program yang berhasil. Kurang perhatian terhadap kualitas akan mengakibatkan kegagalan dalam jangka panjang. Kedua, perbaikan-perbaikan kualitas menuntut komitmen menajemen sepernuhnya untuk dapat berhasil. Komitmen kepada kualitas ini harus terus-menerus. Ketiga, perbaikan kualitas adalah kerja keras. Tidak ada jalan pintas atau perbaikan cepat. Menuntut perbaikan budaya bagi organisasi secara keseluruhan. Keempat, perbaikan kualitas menuntut banyak pelatihan. Kelima, perbaikan kualitas menuntut keterlibatan semua karyawan secara aktif, dan komitmen mutlak dari manajemen senior.

Menurut Crosby, kemutlakan bagi kualitas adalah: (1) kualitas harus disesuaian sebagai kesesuaian terhadap kebutuhan-kebutuhan, bukan sebagai kebaikan, juga bukan keistimewaan, (2) sistem untuk menghasilkan kualitas adalah pencegahan bukan penilaian, (3) standar kerja harus tanpa cacat, bukan "cukup mendekati tanpa cacat", (4) pengukuran kualitas merupakan harga ketidaksesuaian, bukan pedoman. Karena itu, menurut tokoh yang sangat terkemuka dengan gagasan kualitas ini, bahwa manajemen adalah penyebab setidak-tidaknya $80 \%$ masalahmasalah kualitas di dalam organisasi. Karena itu, satu-satunya jalan memperbaikinya adalah melalui kepemimpinan manajemen. Crosby memberikan "vaksin kualitas" (Quality vaccine), yaitu: (1) Tujuan: manajemen merupakan satu-satunya alat yang akan mengubah citra organisasi, (2) Pendidikan: membantu semua komponen organisasi mengembangkan satu pengertian umum tentang kualitas dan memahami peran mereka masing-masing di dalam proses perbaikan kualitas, (3) penerapan: membimbing dan mengarahkan program perbaikan.

Pengertian kulitas terpadu seperti di atas, memberikan kerangka yang jelas bahwa hakekat Total Quality Management atau manajemen kualitas terpadu sebenarnya adalah filosofi dan budaya (kerja) organisasi (phylosopy of management) yang berorentasi pada kualitas. Tujuan (goal) yang akan dicapai dalam organisasi dengan budaya TQM adalah memenuhi atau bahkan melebihi apa yang dibutuhkan 
(needs) dan yang diharapkan atau diinginkan (desire) oleh pelanggan.

Dengan demikian, TQM dapat diartikan sebagai pengelolaan kualitas semua komponen (stakehorder) yang berkepentingan dengan visi dan misi organisasi. Jadi, pada dasarnya TQM itu bukanlah pembebanan ataupun pemeriksaan. Tetapi, TQM adalah lebih dari usaha untuk melakukan sesuatu yang benar setiap waktu, daripada melakukan pemeriksaan (cheking) pada waktu tertentu ketika terjadi kesalahan. TQM bukan bekerja untuk agenda orang lain, walaupun agenda itu dikhususkan untuk pelanggan (customer) dan klien. Demikian juga, TQM bukan sesuatu yang diperuntukkan bagi menajer senior dan kemudian melewatkan tujuan yang telah dirumuskan.

Total Quality Management adalah pelibatan semua komponen organisasi yang berlangsung secara terus-menerus. Sementara manajemen di dalam TQM berarti pengelolaan setiap orang yang berada di dalam organisasi, apapun status, posisi atau perannya. Mereka semua adalah manajer dari tanggung jawab yang dimilikinya. Senada dengan pengertian ini, Lesley dan Malcolm menyatakan bahwa dalam TQM, maka semua fungsionaris organisasi, tanpa kecuali dituntut memiliki tiga kemampuan, yaitu : Pertama, mengerjakan hal-hal yang benar. Ini berarti bahwa hanya kegiatan yang menunjang bisnis demi memuaskan kebutuhan pelanggan yang dapat diterima. Kegiatan yang tidak perlu maka jangan dilanjutkan lagi. Kedua, mengerjakan hal-hal dengan benar. Ini berarti bahwa semua kegiatan harus dijalankan dengan benar, sehingga hasil kegiatan tersebut sesuai dengan kebutuhan pelanggan. Ketiga, mengerjakan hal-hal dengan benar sejak pertama kali setiap waktu. Hal ini dilandasi dengan dasar pemikiran untuk mencegah kesalahan yang timbul. Prinsipnya, menurut Lesley dan Malcolm, TQM itu merupakan suatu pendekatan sistematis terhadap perencanaan dan manajemen aktivitas, yang memiliki motto: Do the right think, first time, every time, yaitu "kerjakan sesuatu yang benar dengan benar, sejak pertama kali, setiap waktu". Total Quality Management merupakan suatu filosofi peningkatan kualitas secara berkelanjutan dan dapat 
dijadikan alat praktis oleh lembaga pendidikan dalam memenuhi kebutuhan, keinginan, dan harapan pelanggan sekarang dan masa mendatang dalam bidang pendidikan (Sallis, 1993: 34). Artinya, kualitas pendidikan difokuskan pada kepuasan pelanggan (internal dan eksternal). TQM juga merupakan aktivitas untuk melakukan segala sesuatu secara benar pada setiap saat. Hal ini didasarkan pada realita bahwa aktivitas tersebut lebih baik dari pada memperbaiki kesalahan. Oleh karena itu, sangatlah tepat apabila tujuan utama TQM dalam pendidikan adalah peningkatan kualitas pendidikan secara terus-menerus.

\section{KURIKULUM PENDIDIKAN ISLAM}

Kurikulum adalah seperangkat rencana dan pengaturan mengenai isi dan bahan pelajaran serta cara yang digunakan sebagai pedoman penyelenggaraan kegiatan pembelajaran untuk mencapai tujuan pendidikan tertentu. (Undang-Undang No.20 TH. 2003 Tentang Sistem Pendidikan Nasional).

Kurikulum adalah seluruh pengalaman pendidikan yang diperoleh oleh peserta didik pada program pendidikan, tujuan-tujuan yang dicapai, yang harus dikembangkan sesuai dengan perkembangan teori, penelitian, implementasi, dan memperhatikan perubahan masyarakat. ${ }^{9}$

Kurikulum pendidikan tinggi adalah seperangkat rencana dan pengaturan mengenai isi maupun bahan kajian dan pelajaran serta cara penyampaian dan penilaiannya yang digunakan sebagai pedoman penyelenggaraan kegiatan belajarmengajar di perguruan tinggi. (Pasal 1 Butir 6 Kemendiknas No.232/U/2000 tentang Pedoman Penyusunan Kurikulum Pendidikan Tinggi dan Penilaian Hasil Belajar Mahasiswa).

Kurikulum adalah serangkaian mata ajar dan pengalaman belajar yang mempunyai tujuan tertentu, yang diajarkan dengan cara tertentu dan kemudian

\footnotetext{
${ }^{9}$ Ahmadi, Manajemen Kurikulum ..., 55.
} 
dilakukan evaluasi. (Badan Standardisasi Nasional SIN 19-7057-2004 tentang Kurikulum Pelatihan Hiperkes dan Keselamatan Kerja Bagi Dokter Perusahaan). ${ }^{10}$

Istilah "Kurikulum" memiliki berbagai tafsiran yang dirumuskan oleh pakarpakar dalam bidang pengembangan kurikulum sejak dulu sampai dewasa ini. Tafsiran-tafsiran tersebut berbeda-beda satu dengan yang lainnya, sesuai dengan titik berat inti dan pandangan dari pakar yang bersangkutan. Istilah kurikulum berasal dari bahas latin, yakni "Curriculae", artinya jarak yang harus ditempuh oleh seorang pelari. Pada waktu itu, pengertian kurikulum ialah jangka waktu pendidikan yang harus ditempuh oleh siswa yang bertujuan untuk memperoleh ijazah. Dengan menempuh suatu kurikulum, siswa dapat memperoleh ijazah. Dalam hal ini, ijazah pada hakikatnya merupakan suatu bukti, bahwa siswa telah menempuh kurikulum yang berupa rencana pelajaran, sebagaimana halnya seorang pelari telah menempuh suatu jarak antara satu tempat ketempat lainnya dan akhirnya mencapai finish. Dengan kata lain, suatu kurikulum dianggap sebagai jembatan yang sangat penting untuk mencapai titik akhir dari suatu perjalanan dan ditandai oleh perolehan suatu ijazah tertentu. ${ }^{11}$

Di Indonesia istilah "kurikulum" boleh dikatakan baru menjadi populer sejak tahun lima puluhan, yang dipopulerkan oleh mereka yang memperoleh pendidikan di Amerika Serikat. Kini istilah itu telah dikenal orang di luar pendidikan. Sebelumnya yang lazim digunakan adalah "rencana pelajaran" pada hakikatnya kurikulum sama sama artinya dengan rencana pelajaran. ${ }^{12}$

Beberapa tafsiran lainnya dikemukakan sebagai berikut ini.

Kurikulum memuat isi dan materi pelajaran. Kurikulum ialah sejumlah mata ajaran yang harus ditempuh dan dipelajari oleh siswa untuk memperoleh sejumlah pengetahuan. Mata ajaran (subject matter) dipandang sebagai pengalaman orang tua atau orang-orang pandai masa lampau, yang telah disusun secara sistematis dan logis.

\footnotetext{
${ }^{10}$ Oemar Hamalik, Kurikulum dan Pembelajaran, (Jakarta : Bumi Aksara, 2007), 18.

${ }^{11}$ Oemar Hamalik, Kurikulum dan Pembelajaran, (Jakarta : Bumi Aksara , 2007), 16.

12 S. Nasution, M.A, Asas-Asas Kurikulum, (Jakarta : Bumi Aksara, 2006), 2.
} 
Mata ajaran tersebut mengisis materi pelajaran yang disampaikan kepada siswa, sehingga memperoleh sejumlah ilmu pengetahuan yang berguna baginya.

Kurikulum sebagai rencana pembelajaran. Kurikulum adalah suatu program pendidikan yang disediakan untuk membelajarkan siswa. Dengan program itu para siswa melakukan berbagai kegiatan belajar, sehingga terjadi perubahan dan perkembangan tingkah laku siswa, sesuai dengan tujuan pendidikan dan pembelajaran. Dengan kata lain, sekolah menyediakan lingkungan bagi siswa yang memberikan kesempatan belajar. Itu sebabnya, suatu kurikulum harus disusun sedemikian rupa agar maksud tersebut dapat tercapai. Kurikulum tidak terbatas pada sejumlah mata pelajaran saja, melainkan meliputi segala sesuatu yang dapat mempengaruhi perkembangan siswa, seperti: bangunan sekolah, alat pelajaran, perlengkapan, perpustakaan, gambar-gambar, halaman sekolah, dan lain-lain; yang pada gilirannya menyediakan kemungkinan belajar secara efektif. Semua kesempatan dan kegiatan yang akan dan perlu dilakukan oleh siswa direncanakan dalam suatu kurikulum.

Kurikulum sebagai pengalaman belajar. Perumusan/pengertian kurikulum lainnya yang agak berbeda dengan pengertian-pengertian sebelumnya lebih menekankan bahwa kurikulum merupakan serangkaian pengalaman belajar. Salah satu pendukung dari pengalaman ini menyatakan sebagai berikut:

"Curriculum is interpreted to mean all of the organized courses, activities, and experiences which pupils have under direction of the school, whether in the classroom or not.

Pengertian itu menunjukan, bahwa kegiatan-kegiatan kurikulum tidak terbatas dalam ruang kelas saja, melainkan mencakup juga kegiatan-kegiatan diluar kelas. Tidak ada pemisahan yang tegas antara intra dan ekstra kurikulum. Semua kegiatan yang memberikan pengalaman belajar/pendidikan bagi siswa pada hakikatnya adalah kurikulum. 
Pendidikan Islam (Tarbiyah al-Islamiyah) oleh para ahli sering diartikan sebagai proses pemeliharaan, pengembangan dan pembinaan. ${ }^{13}$ Muhammad Hamid an-Nashir dan Kulah Abd al-Qadir Darwis mendifinisikan pendidikan Islam sebagai proses pengarahan perkembangan manusia (ri'ayah) pada sisi jasmani, akal, bahasa, tingkah laku, dan kehidupan sosial dan keagamaan yang diarahkan pada kebaikan menuju kesempurnaan. ${ }^{14}$

Pendidikan Islam merupakan pendidikan yang didasarkan pada nilai-nilai ajaran Islam sebagaimana tercantum dalam al-Qur'an dan al-Hadits serta dalam pemikiran para ulama dan dalam praktik sejarah umat Islam. ${ }^{15}$

Dalam prosesnya, pendidikan Islam menjadikan tujuan sebagai sasaran ideal yang hendak dicapai dalam program dan diproses dalam produk kependidikan Islam atau output kependidikan Islam. ${ }^{16}$

Dari berbagai macam pengertian kurikulum dan pendidikan Islam diatas kita dapat menarik garis besar pengertian kurikulum pendidikan Islam adalah seperangkat rencana dan pengaturan mengenai tujuan, isi, dan bahan pelajaran serta cara yang digunakan sebagai pedoman penyelenggaraan kegiatan pembelajaran untuk mencapai tujuan pendidikan Islam.

\footnotetext{
${ }^{13}$ M. Irsyad Djuwaeli, Pembaruan Kembali Pendidikan Islam(Ciputat: Karsa Utama Mandiri, 1998), 3. ${ }^{14}$ Moh. Roqib, Ilmu Pendidikan Islam, (Yogyakarta: PT. Lkis Printing Cemerlang, 2009), hlm 15.

${ }^{15}$ Abudin Nata,Manajemen Pendidikan, Mengatasi Kelemahan Pendidikan Islam di Indonesia,(Jakarta: Prenada Media Group, 2008), cet ke.3, 173.

${ }^{16} \mathrm{M}$. Arifin, Ilmu Pendidikan Islam, Tinjauan Teoritis dan Praktis Berdasarkan Pendekatan Interdisipliner, (Jakarta: Bumi Aksara, 2009), 162.
} 


\section{MANAJEMEN STRATEGI DAN MANAJEMEN MUTU TERPADU SEBAGAI KAJIAN MANAJEMEN KURIKULUM PENDIDIKAN ISLAM}

Sebagai suatu proses atau system pengelolaan, kegiatan-kegiatan pengelolaan pada suatu system pendidikan bertujuan untuk keterlaksanaan proses belajar mengajar yang baik, yang mencakup: ${ }^{17}$

1. Program kurikulum;

2. Program ketenagaan;

3. Program pengadaan dan pemeliharaan fasilitas dan alat-alat pendidikan;

4. Program pembiayaan;

5. Program hubungan dengan masyarakat.

Manajemen strategis dan manajemen mutu terpadu sangat memberikan manfaat dalam perencanaan kurikulum. Sekolah merupakan institusi pendidikan yang hampir sama dengan korporasi- korporasi lainnya yang memerlukan perencanaan strategis untuk menentukan arah jalannya organisasi sekolah supaya lebih jelas arah kebijakan yang akan diambil. Perencanaan strategis dapat memberikan banyak manfaat dilingkungan sekolah/ madrasah bila dibandingkan dengan kelemah- kelemahannya. Manfaat dari perencanaan strategic yaitu

1. Dapat memberikan pedoman yang konsisten bagi kegiatan- kegiatan organisasi,

2. Membantu para pengelola dalam membuat keputusan, analisa hati- hati dari perencanaan strategic memberikan kepada para manajer lebih banyak informasi yang mereka perlukan untuk membuat keputusan-keputusan terbaiknya,

\footnotetext{
${ }^{17}$ Oemar Hamalik, Manajemen Pengembangan Kurikulum (Bandung: PT. Remaja Rosdakarya,2006),75-76.
} 
3. Dapat meminimkan kemungkinan kesalahan karena tujuan atau sasaran dan strategi dirumuskan dengan cermat. ${ }^{18}$

Hal tersebut akan mengurangi kesalahan atau kemungkinan untuk dapat dikerjakan. Dalam dunia pendidikan, kebijakan yang didasarkan pada analisa strategis sangat menentukan kesuksesan yang akan dicapai dimasa yang akan datang karena kebijakan- kebijakan tersebut menggunakan perhitungan yang sangat matang dan komprehensif berdasarkan analisis perubahan-perubahan dan tuntutan baik eksternal (ekonomi, politik, social dan IT) maupun internal ( sumber daya manusia, financial, kesehatan organisasi). Dalam rangka mencapai tujuan tujuan pendidikan tersebut, manajemen strategis memiliki fungsi yang sangat fital.

Manfaat perencanaan strategis yang lebih sederhana ada dua yaitu:

1. Protective Benefits; yang dihasilkan dari pengurangan kemungkinan terjadi kesalahan dalam pembuatan keputusan,

2. Positive Benefits; yang dihasilkan dari meningkatnys sukses pencapaian tujuan. ${ }^{19}$

\footnotetext{
${ }^{18}$ Handoko,Manajemen (Yogyakarta: BPFE, 2003),99.

${ }^{19}$ Ahmadi, Manajemen Kurikulum.....,54.
} 


\section{PENUTUP}

\section{Kesimpulan}

Manajemen strategi adalah suatu proses yang berkenaan dengan penentuan arah masa depan suatu organisasi dan pelaksanaan keputusan dalam rangka mencapai sasaran jangka pendek dan jangka panjang. Menurut Lubis manajemen strategi merupakan proses iterative yang kontinyu untuk menyelaraskan organisasi secara keseluruhan terhadap lingkungannya.

Total Quality Management adalah pelibatan semua komponen organisasi yang berlangsung secara terus-menerus. Sementara manajemen di dalam TQM berarti pengelolaan setiap orang yang berada di dalam organisasi, apapun status, posisi atau perannya. Mereka semua adalah manajer dari tanggung jawab yang dimilikinya.

Manajemen strategis dan manajemen mutu terpadu sangat memberikan manfaat dalam perencanaan kurikulum. Sekolah merupakan institusi pendidikan yang hampir sama dengan korporasi- korporasi lainnya yang memerlukan perencanaan strategis untuk menentukan arah jalannya organisasi sekolah supaya lebih jelas arah kebijakan yang akan diambil. Perencanaan strategis dapat memberikan banyak manfaat dilingkungan sekolah/ madrasah bila dibandingkan dengan kelemah- kelemahannya. Manfaat dari perencanaan strategic yaitu

4. Dapat memberikan pedoman yang konsisten bagi kegiatan- kegiatan organisasi,

5. Membantu para pengelola dalam membuat keputusan, analisa hati- hati dari perencanaan strategic memberikan kepada para manajer lebih banyak informasi yang mereka perlukan untuk membuat keputusan-keputusan terbaiknya,

Dapat meminimkan kemungkinan kesalahan karena tujuan atau sasaran dan strategi dirumuskan dengan cermat. 


\section{DAFTAR PUSTAKA}

Ahmadi, Manajemen Kurikulum: Pendidikan Kecakapan HiduP. Yogyakarta: Pustaka Ifada, 2013.

Arifin, M. Ilmu Pendidikan Islam, Tinjauan Teoritis dan Praktis Berdasarkan Pendekatan Interdisipliner. Jakarta: Bumi Aksara, 2009.

Djuwaeli, M. Irsyad. Pembaruan Kembali Pendidikan Islam. Ciputat: Karsa Utama Mandiri, 1998.

Gunur, Alex. Manjemen Kerangka-Kerangka Pokok. Jakarta: Bhratara Karya Aksara, 1982.

Hamalik, Oemar. Manajemen Pengembangan Kurikulum. Bandung: PT. Remaja Rosdakarya,2006.

Oemar. Kurikulum dan Pembelajaran. Jakarta : Bumi Aksara, 2007.

Handoko, T. Hani. Manajemen. Yogyakarta: BPFE, 2003.

Mulyasana, E. Pendidikan Bermutu dan Berdaya Saing. Bandung: PT. Remaja Rosda Karya, 2011.

Nasution, M.A, S. Asas-Asas Kurikulum. Jakarta : Bumi Aksara, 2006.

Nata, Abudin. Manajemen Pendidikan, Mengatasi Kelemahan Pendidikan Islam di Indonesia, Jakarta: Prenada Media Group, 2008.

Ramayulis,IlmuPendidikanIslam. Jakarta: KalamMulia,2008.

Roqib, Moh. Ilmu Pendidikan Islam. Yogyakarta: PT. Lkis Printing Cemerlang, 2009.

Tilaar, H.A.R. Membenahi PendidikanNasional. Jakarta: PT.Rineka Cipta, 2002.

Wijaya, David Implementasi Manajemen Mutu Terpadu dalam Penyelenggaraan Pendidikan di sekolah "Jurnal Pendidikan Penabur - No.10/Tahun ke-7/Juni 2008,hlm 89 